\title{
Experimental Investigation of an Indirect Evaporative Cooler Consisting of a Heat Pipe Embedded in Porous Ceramic
}

\author{
S. Riffat* and J. Zhu \\ School of the Built Environment, University of Nottingham, NG7 2RD, UK
}

Received 24 May 2003; accepted 5 November, 2003

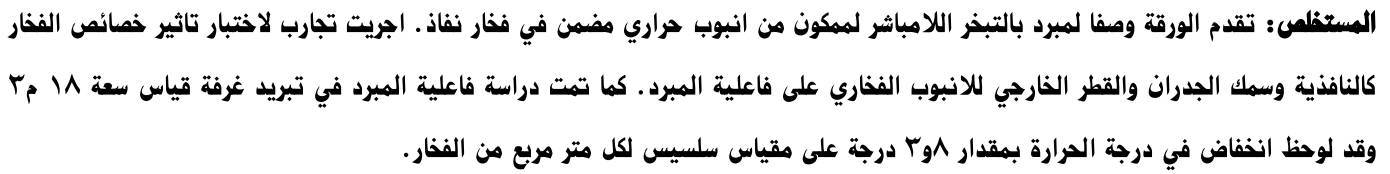

الهزرداه الهنتاهية: انبوب حراري ، فخار نفاذ، سقف تبريد، التبريد بالتبخر اللامباشر .

\begin{abstract}
An indirect evaporative cooler incorporating a porous ceramic and a heat pipe was described. Experiments were carried out to examine the effects of various ceramic properties, such as porosity, wall thickness, and outside diameter. Use of the cooler for a chilled ceiling in an environmental chamber was also investigated. A temperature drop of $3.8^{\circ} \mathrm{C}$ per square metre of ceramic surface area was achieved for an $18 \mathrm{~m}$ chamber.
\end{abstract}

Keywords: Heat pipe, porous ceramic, Chilled ceiling, Indirect evaporative cooling

\section{Introduction}

Requirements for comfortable living and working conditions have resulted in an increased demand for air conditioning. The latter is normally carried out using a vapour compression system powered by electricity and incorporating a chlorofluorocarbon (CFC) refrigerant. Generation of electricity by conventional means results in vast quantities of $\mathrm{CO}_{2}$ being released to the atmosphere. Concerns over global warming and the environmental damage caused by CFC refrigerants have stimulated research to develop alternate systems for air conditioning. One such system is based on evaporative cooling. This technique eliminates environmental damage and offers energy savings in running costs. Among the various methods of evaporative cooling, indirect evaporative cooling has been used widely in industrial and commercial air conditioning (Joudi and Mehdi, 2000; Suri, 2001), not only because it operates at very low energy cost, but also because it cools the air without adding moisture to it. Indirect evaporative cooling may be applied to buildings in the form of a chilled ceiling. This technique is becoming increasingly popular in many European countries as an alternative means of air conditioning (Costelloe and Finn, 2003; Gasparella and Longo, 2003).

*Corresponding author Email:saffa.riffat@nottingham.ac.uk
Indirect evaporative coolers use evaporation of moisture in the outside air to produce a cooling effect. This is transferred to the supply air via a heat exchaner or thermal conductor without the addition of moisture to the supply stream.

\section{Methodology}

\subsection{Cooler Description}

The cooler consists of a porous ceramic and a heat pipe (Riffat, 2001), Figure 1. The cool source is a porous ceramic filled with water. When outside dry air passes across the surface of the ceramic, it causes water to siphon to its surface through the multitude of pores. The water then evaporates and creates a cooling effect. The heat pipe used in this system acts as the heat exchanger, and transfers the coolness to the supply air. The condenser section of the heat pipe is embedded in the porous ceramic, Figure 2 . The air supply stream is cooled when it passes across the evaporator section of the heat pipe. Its heat is absorbed by the heat pipe's working fluid, causing the latter to evaporate. The vapour then condenses at the condenser section of the heat pipe and surrenders its heat to the water in the ceramic.

\subsection{Porous ceramic}

This experimental investigation studied the effects of 


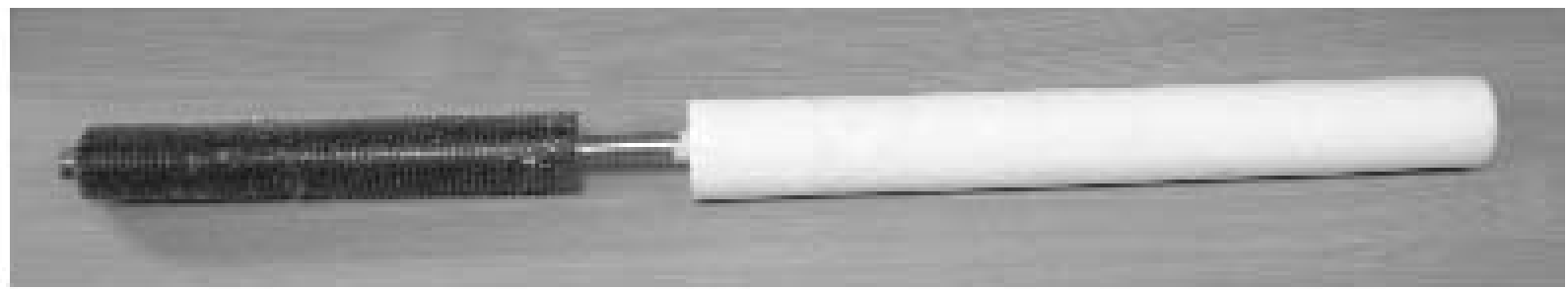

Figure 1. Cooler with heat pipe embedded in porous ceramic

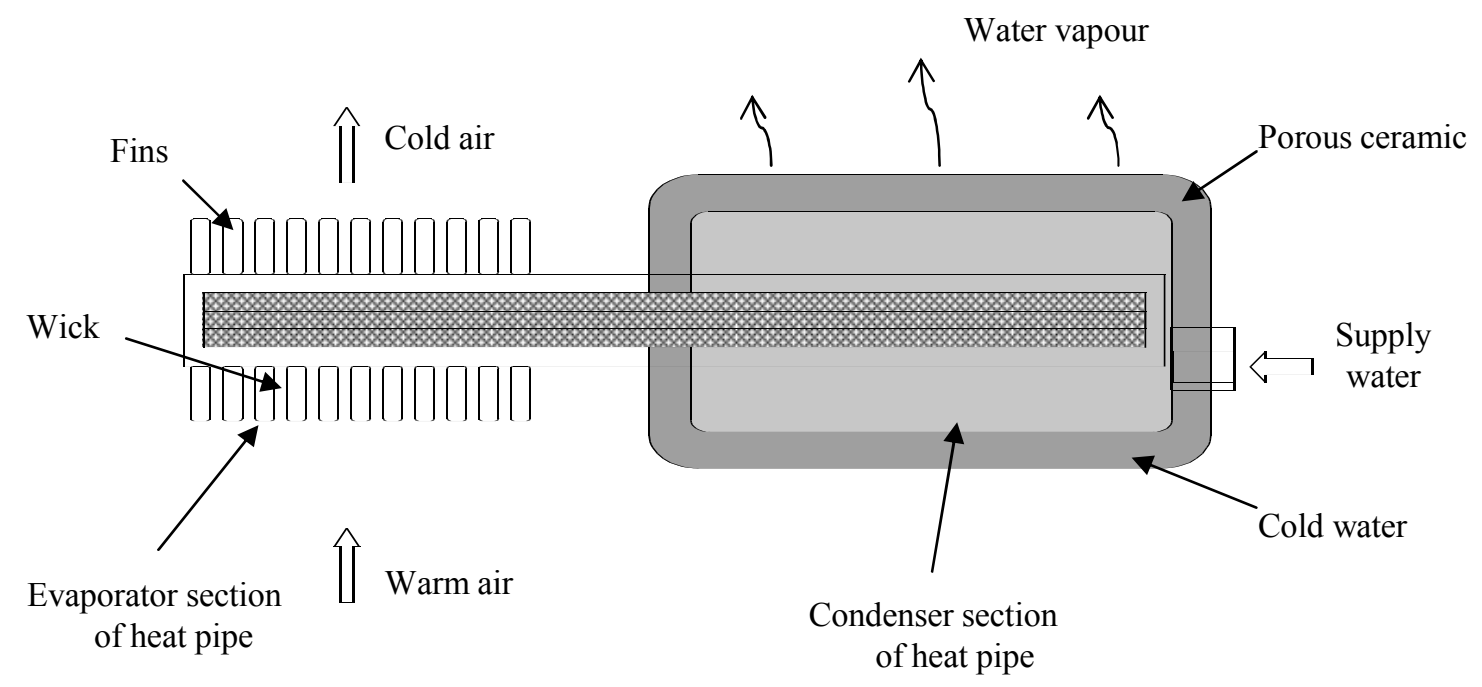

Figure 2. Indirect evaporative

several factors on the performance of the ceramic cooler.

\subsubsection{Ceramic porosity}

The ceramics were made from clay material with the chemical composition shown in Table 1. However, the

Table 1. Ceramic composition

\begin{tabular}{cc}
\hline Component & Composition (\%) \\
\hline $\mathrm{SiO}_{2}$ & 69.39 \\
$\mathrm{Al}_{2} \mathrm{O}_{2}$ & 19.23 \\
$\mathrm{Fe}_{2} \mathrm{O}_{3}$ & 0.47 \\
$\mathrm{TiO}_{2}$ & 0.26 \\
$\mathrm{MgO}$ & 0.18 \\
$\mathrm{CaO}$ & 0.84 \\
$\mathrm{~K} 2 \mathrm{O}$ & 1.62 \\
$\mathrm{Na}_{2} \mathrm{O}$ & 0.36 \\
$\mathrm{LOI}$ & 6.91 \\
\hline
\end{tabular}

Table 2. Ceramic fired

\begin{tabular}{ccc}
\hline $\begin{array}{c}\text { Porosity } \\
\mathbf{\%}\end{array}$ & $\begin{array}{c}\text { Firing Temperature } \\
\left({ }^{\mathbf{0}} \mathbf{C}\right)\end{array}$ & $\begin{array}{c}\text { Firing Cycle } \\
\text { (hr) }\end{array}$ \\
\hline 29.7 & 1020 & 6.5 \\
32.8 & 950 & 5.5 \\
34.6 & 810 & 4.5 \\
\hline
\end{tabular}

processes of manufacture were different and ceramics with different apparent porosities were obtained from batches fired at different temperatures, Table 2. The expressed porosity is a percentage by volume, and it was determined from the amount of water absorbed by the ceramic.

\subsubsection{Ceramic wall thickness}

Ceramics with different wall thickness, i.e., $10 \mathrm{~mm}$, $15 \mathrm{~mm}$ and $20 \mathrm{~mm}$, were investigated. The outside dimensions of the ceramics were kept constant and so consequently the inside volumes were slightly different in each case.

\subsubsection{Ceramic outside dimension}

Cylindrical ceramics with diameters of $60 \mathrm{~mm}, 120 \mathrm{~mm}$ and $240 \mathrm{~mm}$ were investigated with other parameters being kept the same. The cylindrical surface area for water evaporation therefore increased proportionately.

\subsubsection{Thermal conductivity}

Copper wool was packed between the ceramic and the heat pipe when the investigation of thermal conductivity was carried out. Heat was therefore transferred from the heat pipe to the ceramic by both water and copper wool under this condition. 


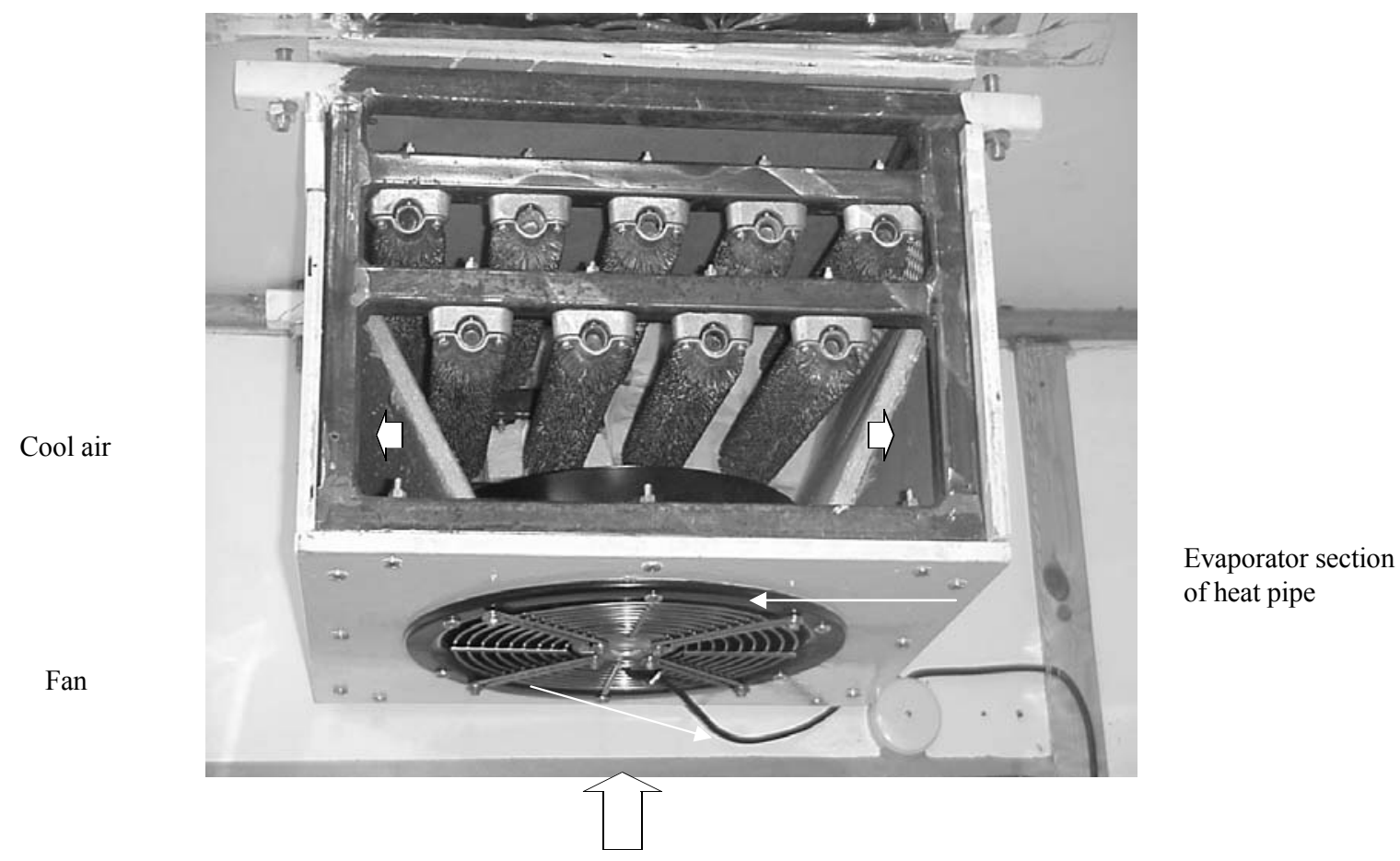

Figure 3. Chilled Ceiling

Hot air

\subsection{Cooler Construction}

\subsubsection{Cooler unit}

The sealed tube of the heat pipe was constructed of phosphorus deoxidized non-arsenical copper. The tube had an outside diameter $20 \mathrm{~mm}$ and length $950 \mathrm{~mm}$; the fin height was $15 \mathrm{~mm}$ and the length of the evaporative section was $350 \mathrm{~mm}$. The length of the heat pipe condenser section (embedded in ceramic) was $400 \mathrm{~mm}$. A screen mesh was used as the wick of the heat pipe, and the working fluid was distilled water. The outside length of the ceramic was $420 \mathrm{~mm}$.

\subsubsection{Chilled ceiling}

A group of indirect evaporative coolers was assembled to form the chilled ceiling, Figure 3. Ceramics with a porosity of $32.8 \%$, an outside diameter of $60 \mathrm{~mm}$ and a wall thickness of $10 \mathrm{~mm}$, without copper wool, were used. Only the evaporative section of the heat pipe was fixed in the frame. The chilled ceiling dimension was $450 \mathrm{~mm}(\mathrm{~L})$ $\times 420 \mathrm{~mm}(\mathrm{~W}) \times 340 \mathrm{~mm}(\mathrm{H})$. The evaporator section of the heat pipe was in the room and a fan was used to blow the room hot air through the heat pipe evaporative section from the bottom of the chilled ceiling. The cooled air left from both sides of the ceiling and returned to the room. After becoming hot, the air was recycled. The adiabatic heat pipe section was in the wall of room. The porous ceramics were on the outside of the room. The total surface area for water evaporation was $0.712 \mathrm{~m}^{2}$.

\subsection{Experiments}

\subsubsection{Cooler test}

The cooler apparatus largely consisted of two wind tunnels that were thermally isolated from their surroundings, Figure 4. The ceramics were installed in the outside air stream tunnel. The evaporator section of the heat pipes was installed in the supply air stream tunnel. The adiabatic section of the heat pipe was between the two tunnels. Each tunnel had an air velocity sensor, and two temperature sensors for inlet and outlet air streams. In the outside air stream tunnel, two humidity sensors were installed for measuring the inlet and outlet air humidities. All sensors were connected to a datataker that sent the data to a computer. The air stream velocities were adjusted via two fans. A humidifier or dehumidifier controlled the inlet humidity of the outside air stream. Heaters regulated the inlet air stream temperatures of the two tunnels.

A total of nine types of ceramic were tested in this study. They were divided into three groups; one group with different porosities, a second group with different wall thicknesses, and the third group with different outside diameters. Each group of ceramics was tested under the same inlet air stream parameters, e.g., temperature, velocity and humidity. The thermal conductivity test was carried out using ceramics with copper wool. Ceramics with, and without, copper wool were tested under the same conditions.

The cooling capacity $\mathrm{Q}$ is defined as: 


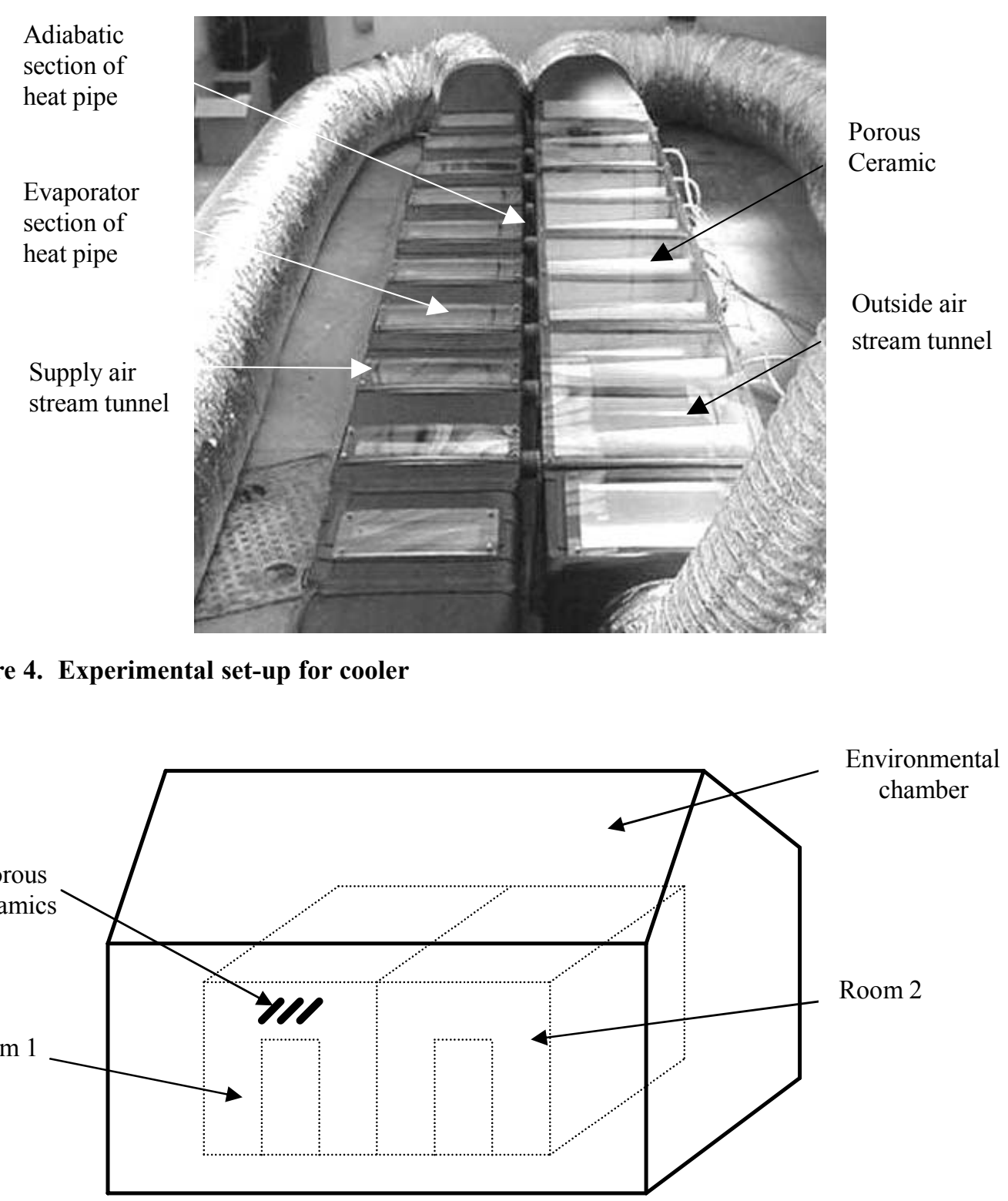

Figure 5. Environmental Chamber

$$
Q=\frac{V_{3} S_{3} \rho C_{\mathrm{p}}\left(T_{3}-T_{4}\right)}{S_{s}}
$$

Herein, $V_{3}$ is the supply air stream velocity, $S_{3}$ is the crosssectional area of the supply air stream tunnel, $\rho$ is the air density of the supply air stream, $C_{p}$ is the specific heat capacity of the supply air stream, $T_{3}$ and $T_{4}$ are the inlet and outlet air temperatures of supply air stream, respectively, and $S_{c}$ is the total surface area of ceramic for water evaporation in outside air stream tunnel.

\subsubsection{Chilled ceiling test}

The chilled ceiling test was carried out using an environmental chamber, Figure. 5. Two identical rooms in the chamber were selected based on the cooler performance.
The walls of the rooms were made of a sandwich of $3 \mathrm{~mm}$ wood board, $50 \mathrm{~mm}$ polystyrene board and $3 \mathrm{~mm}$ wood board. The roofs were $3 \mathrm{~mm}$ wood board, $50 \mathrm{~mm}$ polystyrene board and $20 \mathrm{~mm}$ wood board. The inside dimensions of each room were $3 \mathrm{~m}(\mathrm{~L}) \times 2.4 \mathrm{~m}(\mathrm{~W}) \times 2.5 \mathrm{~m}(\mathrm{H})$. The chilled ceiling was installed in Room 1.

Seven temperature sensors and two humidity sensors were installed in the environmental chamber in order to measure the surrounding temperature and humidity. There were eight temperature sensors in each room to allow an average room temperature to be obtained. All sensors were connected to a datataker attached to a computer. The two rooms had the same heat loads throughout the experiments. Prior to the tests, they had the same temperature. The doors and windows of the two rooms were closed during the tests. 
Table 3. Effect of ceramic porosity

\begin{tabular}{|c|c|c|c|c|c|c|c|c|c|}
\hline \multirow{3}{*}{$\begin{array}{c}\text { Porosity } \\
\text { (\%) }\end{array}$} & \multicolumn{5}{|c|}{ Outside air tunnel } & \multicolumn{3}{|c|}{ Supply air tunnel } & \multirow{3}{*}{$\begin{array}{c}\mathbf{Q} \\
\left(W / \mathbf{m}^{2}\right)\end{array}$} \\
\hline & \multicolumn{2}{|c|}{ Inlet } & \multicolumn{2}{|c|}{ Outlet } & \multirow{2}{*}{$\begin{array}{l}\text { Velocity } \\
V_{1}(\mathrm{~m} / \mathrm{s}) \\
\end{array}$} & \multirow{2}{*}{$\begin{array}{c}\text { Inlet } \\
T_{3}\left({ }^{\circ} \mathrm{C}\right) \\
\end{array}$} & \multirow{2}{*}{$\begin{array}{l}\text { Outlet } \\
T_{4}\left({ }^{\circ} \mathrm{C}\right) \\
\end{array}$} & \multirow{2}{*}{$\begin{array}{l}\text { Velocity } \\
V_{3}(\mathrm{~m} / \mathrm{s})\end{array}$} & \\
\hline & T1(oC) & $\mathrm{RH}_{1}(\%)$ & $\mathrm{T}_{2}\left({ }^{\circ} \mathrm{C}\right)$ & $\mathrm{RH}_{2}(\%)$ & & & & & \\
\hline \multirow{3}{*}{29.7} & 35.4 & 22.4 & 31.8 & 33.6 & 1.08 & 35.0 & 32.2 & 0.36 & 29.70 \\
\hline & 35.2 & 22.9 & 31.9 & 32.2 & 1.56 & 34.9 & 31.8 & 0.37 & 33.58 \\
\hline & 35.2 & 23.1 & 32.2 & 31.6 & 2.03 & 35.2 & 31.9 & 0.39 & 36.05 \\
\hline \multirow{3}{*}{32.8} & 34.9 & 40.3 & 31.4 & 57.1 & 1.07 & 35.2 & 32.0 & 0.44 & 41.03 \\
\hline & 35.6 & 36.6 & 32.0 & 51.5 & 1.52 & 35.3 & 31.9 & 0.46 & 44.68 \\
\hline & 35.3 & 37.6 & 31.9 & 51.2 & 1.97 & 35.4 & 31.9 & 0.46 & 46.49 \\
\hline \multirow{3}{*}{34.6} & 35.1 & 35.0 & 30.9 & 52.3 & 1.14 & 35.1 & 31.1 & 0.46 & 52.52 \\
\hline & 35.3 & 32.8 & 31.4 & 47.6 & 1.58 & 35.1 & 31.0 & 0.46 & 53.35 \\
\hline & 35.6 & 32.9 & 31.6 & 46.7 & 2.01 & 35.2 & 30.5 & 0.43 & 59.21 \\
\hline
\end{tabular}

Table 4. Effect of ceramic wall thickness

\begin{tabular}{|c|c|c|c|c|c|c|c|c|c|}
\hline \multirow{3}{*}{$\begin{array}{l}\text { Thick } \\
\text { - ness } \\
\text { (mm) }\end{array}$} & \multicolumn{5}{|c|}{ Outside air tunnel } & \multicolumn{3}{|c|}{ Supply air tunnel } & \multirow{3}{*}{$\begin{array}{c}\mathbf{Q} \\
\frac{\left(W / \mathrm{m}^{2}\right)}{}\end{array}$} \\
\hline & \multicolumn{2}{|c|}{ Inlet } & \multicolumn{2}{|c|}{ Outlet } & \multirow{2}{*}{$\begin{array}{l}\text { Velocity } \\
V_{1}(\mathrm{~m} / \mathrm{s})\end{array}$} & \multirow{2}{*}{$\begin{array}{c}\text { Inlet } \\
\mathrm{T}_{3}\left({ }^{\circ} \mathrm{C}\right)\end{array}$} & \multirow{2}{*}{$\begin{array}{l}\text { Outlet } \\
\mathrm{T}_{4}\left({ }^{\circ} \mathrm{C}\right)\end{array}$} & \multirow{2}{*}{$\begin{array}{l}\text { Velocity } \\
V_{3}(\mathrm{~m} / \mathrm{s})\end{array}$} & \\
\hline & $\mathrm{T} 1\left({ }^{\circ} \mathrm{C}\right)$ & $\mathrm{RH}_{1}(\%)$ & $\mathrm{T}_{2}\left({ }^{\circ} \mathrm{C}\right)$ & $\mathrm{RH}_{2}(\%)$ & & & & & \\
\hline \multirow{3}{*}{10} & 35.3 & 32.8 & 31.4 & 47.6 & 1.58 & 35.1 & 31.0 & 0.46 & 53.35 \\
\hline & 35.6 & 32.9 & 31.6 & 46.7 & 2.01 & 35.2 & 30.5 & 0.43 & 59.21 \\
\hline & 35.2 & 33.2 & 31.4 & 46.3 & 2.31 & 34.9 & 29.8 & 0.42 & 62.40 \\
\hline \multirow{3}{*}{15} & 35.4 & 27.0 & 30.8 & 44.6 & 1.53 & 35.5 & 31.8 & 0.46 & 48.94 \\
\hline & 35.8 & 31.6 & 31.8 & 46.2 & 2.01 & 35.8 & 31.7 & 0.46 & 53.72 \\
\hline & 35.6 & 31.4 & 31.7 & 45.2 & 2.31 & 35.7 & 31.4 & 0.46 & 56.71 \\
\hline \multirow{3}{*}{20} & 35.3 & 29.5 & 31.7 & 42.8 & 1.57 & 35.0 & 31.5 & 0.43 & 43.63 \\
\hline & 35.3 & 30.5 & 31.7 & 43.2 & 2.02 & 35.1 & 31.2 & 0.42 & 47.83 \\
\hline & 35.6 & 32.5 & 32.4 & 43.3 & 2.35 & 35.5 & 31.5 & 0.46 & 52.67 \\
\hline
\end{tabular}

Table 5. Effect of ceramic outside diameter

\begin{tabular}{|c|c|c|c|c|c|c|c|c|c|}
\hline \multirow{3}{*}{$\begin{array}{l}\text { Dia- } \\
\text { meter } \\
(\mathrm{mm})\end{array}$} & \multicolumn{5}{|c|}{ Outside air tunnel } & \multicolumn{3}{|c|}{ Supply air tunnel } & \multirow{3}{*}{$\frac{Q}{\left(W / \mathbf{m}^{2}\right)}$} \\
\hline & \multicolumn{2}{|c|}{ Inlet } & \multicolumn{2}{|c|}{ Outlet } & \multirow{2}{*}{$\begin{array}{l}\text { Velocity } \\
V_{1}(\mathrm{~m} / \mathrm{s})\end{array}$} & \multirow{2}{*}{$\begin{array}{c}\text { Inlet } \\
T_{3}\left({ }^{\circ} \mathrm{C}\right)\end{array}$} & \multirow{2}{*}{$\begin{array}{l}\text { Outlet } \\
T_{4}\left({ }^{\circ} \mathrm{C}\right)\end{array}$} & \multirow{2}{*}{$\begin{array}{l}\text { Velocity } \\
V_{3}(\mathrm{~m} / \mathrm{s})\end{array}$} & \\
\hline & $\mathrm{T}_{1}\left({ }^{0} \mathrm{C}\right)$ & $\mathrm{RH}_{1}(\%)$ & $\mathrm{T}_{2}\left({ }^{\circ} \mathrm{C}\right)$ & $\mathrm{RH}_{2}(\%)$ & & & & & \\
\hline 60 & 35.7 & 33.6 & 33.8 & 42.7 & 0.59 & 35.2 & 32.6 & 0.42 & 65.65 \\
\hline 120 & 35.4 & 37.0 & 30.8 & 61.6 & 0.43 & 35.4 & 32.3 & 0.44 & 40.24 \\
\hline 240 & 35.2 & 37.7 & 27.2 & 72.7 & 0.54 & 35.4 & 31.1 & 0.45 & 28.17 \\
\hline
\end{tabular}

Table 6. Effect of thermal conductivity

\begin{tabular}{|c|c|c|c|c|c|c|c|c|c|}
\hline \multirow{3}{*}{$\begin{array}{c}\text { With } \\
\text { copper } \\
\text { wool }\end{array}$} & \multicolumn{5}{|c|}{ Outside air tunnel } & \multicolumn{3}{|c|}{ Supply air tunnel } & \multirow{3}{*}{$\begin{array}{c}\mathbf{Q} \\
\left(\mathbf{W} / \mathbf{m}^{2}\right)\end{array}$} \\
\hline & \multicolumn{2}{|c|}{ Inlet } & \multicolumn{2}{|c|}{ Outlet } & \multirow{2}{*}{$\begin{array}{l}\text { Velocity } \\
V_{1}(\mathrm{~m} / \mathrm{s})\end{array}$} & \multirow{2}{*}{$\begin{array}{c}\text { Inlet } \\
T_{3}\left({ }^{\circ} \mathrm{C}\right)\end{array}$} & \multirow{2}{*}{$\begin{array}{l}\text { Outlet } \\
\mathrm{T}_{4}\left({ }^{\circ} \mathrm{C}\right)\end{array}$} & \multirow{2}{*}{$\begin{array}{l}\text { Velocity } \\
V_{3}(\mathrm{~m} / \mathrm{s}\end{array}$} & \\
\hline & $\mathrm{T}_{1}\left({ }^{0} \mathrm{C}\right)$ & $\mathrm{RH}_{1}(\%)$ & $\mathrm{T}_{2}\left({ }^{\circ} \mathrm{C}\right)$ & $\mathrm{RH}_{2}(\%)$ & & & & & \\
\hline \multirow{5}{*}{ No } & 35.2 & 33.5 & 30.1 & 59.4 & 0.43 & 35.2 & 32.0 & 0.46 & 42.26 \\
\hline & 35.0 & 33.3 & 30.7 & 51.9 & 1.07 & 34.9 & 31.4 & 0.45 & 45.80 \\
\hline & 35.4 & 27.0 & 30.8 & 44.6 & 1.53 & 35.5 & 31.8 & 0.46 & 48.94 \\
\hline & 35.8 & 31.6 & 31.8 & 46.2 & 2.01 & 35.8 & 31.7 & 0.46 & 53.72 \\
\hline & 35.6 & 31.4 & 31.7 & 45.2 & 2.31 & 35.7 & 31.4 & 0.46 & 56.71 \\
\hline \multirow{5}{*}{ Yes } & 35.6 & 27.1 & 29.7 & 55.5 & 0.49 & 35.7 & 32.4 & 0.48 & 45.15 \\
\hline & 35.4 & 27.2 & 30.2 & 47.9 & 1.04 & 35.5 & 31.9 & 0.47 & 48.45 \\
\hline & 35.8 & 33.9 & 31.1 & 51.0 & 1.52 & 35.3 & 31.4 & 0.46 & 52.36 \\
\hline & 34.8 & 33.9 & 30.5 & 49.5 & 2.02 & 35.2 & 30.7 & 0.45 & 59.09 \\
\hline & 36.0 & 30.0 & 31.2 & 45.1 & 2.30 & 35.6 & 31.0 & 0.48 & 63.27 \\
\hline
\end{tabular}




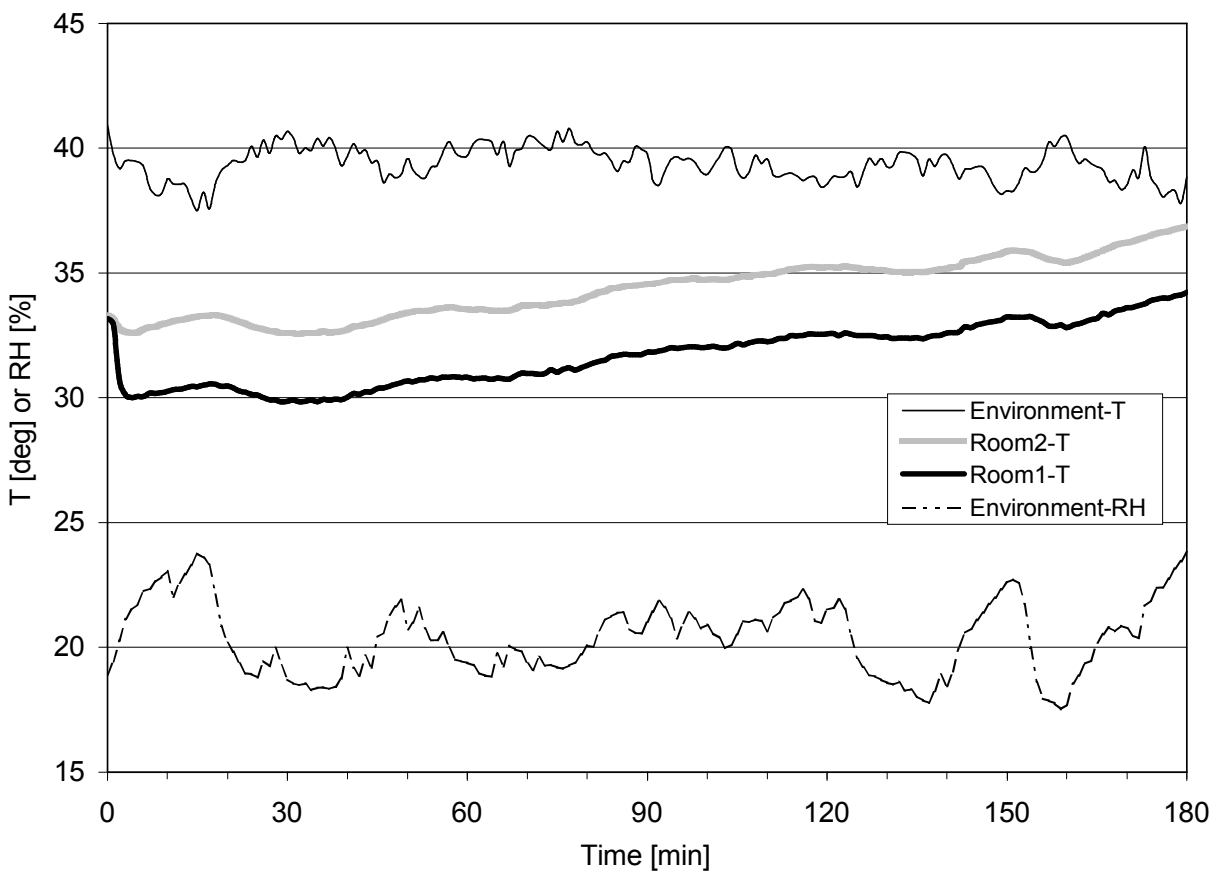

Figure 6. Room temperature in environmental chamber

\section{Results and Discussion}

\subsection{Cooler}

\subsubsection{Effect of ceramic porosity}

It was found that cooling capacity increased with ceramic porosity due to increased evaporation for ceramics with high permeability, Table 3 . For example, cooling capacity increased from $44.68 \mathrm{~W} / \mathrm{m}^{2}$ to $53.35 \mathrm{~W} / \mathrm{m}^{2}$ as the porosity increased from $32.8 \%$ to $34.6 \%$ under the same inlet air conditions (including outside air tunnel temperature $T_{1}$, relative humidity $\mathrm{RH}_{1}$ and velocity $V_{1}$, and supply air tunnel $\mathrm{T}_{3}$ and $\mathrm{V}_{3}$ ). The average rate of increase of cooling capacity was $4.89\left(\mathrm{~W} / \mathrm{m}^{2}\right) / \%$ within this air velocity range.

\subsubsection{Effect of ceramic wall thickness}

Cooling capacity decreased with increasing ceramic wall thickness, as shown in Table 4. For example, cooling capacity decreased from $59.21 \mathrm{~W} / \mathrm{m}^{2}$ to $53.72 \mathrm{~W} / \mathrm{m}^{2}$ as ceramic wall thickness increased from $10 \mathrm{~mm}$ to $15 \mathrm{~mm}$ under the same inlet air conditions. This was due to the increased resistance to water permeance at greater wall thicknesses. The average decreasing rate of cooling capacity was $1.03\left(\mathrm{~W} / \mathrm{m}^{2}\right) / \mathrm{mm}$. The ceramic wall should therefore be as thin as possible taking into account design strength limitations.

\subsubsection{Effect of ceramic outside diameter}

Cooling capacity decreased with increasing outside diameter as shown in Table 5, even though the total cool- ing ability ( $Q$ multiply surface area) increased. For example, cooling capacity decreased from $65.65 \mathrm{~W} / \mathrm{m}^{2}$ to 28.17 $\mathrm{W} / \mathrm{m}^{2}$ as ceramic outside diameter increased from $60 \mathrm{~mm}$ to $240 \mathrm{~mm}$ under the same inlet air conditions. This was due to increasing heat transfer resistance between the heat pipe condenser and the ceramic as the ceramic diameter increased. This demonstrated that it is not possible to enhance the cooler performance continuously by solely increasing the surface area of ceramic. The heat transfer resistance needs to be considered simultaneously. In these tests, the ceramic outside dimensions had an influence on air flow modes in the outside tunnel. This uncertainty effect will be considered in future investigations.

\subsubsection{Effect of thermal conductivity}

Cooling capacities were enhanced when copper wool was inserted into the ceramic, Table 6 . For example, the cooling capacity increased from $48.94 \mathrm{~W} / \mathrm{m}^{2}$ to 52.36 $\mathrm{W} / \mathrm{m}^{2}$ under the same inlet air conditions. This was because the thermal conductivity of water is very low compared with the heat pipe. The main heat transfer resistance was due to the water in the ceramic. Copper has a high thermal conductivity, and so the heat transfer ability was improved by packing copper wool into the ceramic. The average increase in the rate of cooling capacity was $8.2 \%$ in these tests.

\subsection{Chilled ceiling}

The variations in the temperatures of the two rooms were the same, Figure 6 . The heat transfer and internal heat load were the same for the two rooms. The temperature difference of the two rooms was therefore achieved by 
the chilled ceiling. Initially, the temperatures of the rooms were the same. The temperature of Room 1 fell quickly at the beginning but after 3 minutes the temperature difference became almost constant. A temperature drop of 3.8 ${ }^{\circ} \mathrm{C}$ per square metre of ceramic surface area was achieved under the average temperature $39.4{ }^{\circ} \mathrm{C}$ and the average relative humidity $20.3 \%$ of environmental chamber.

\section{Conclusions}

The performance of an indirect evaporative cooler with a porous ceramic and a heat pipe was investigated. The application of the cooler to a chilled ceiling was also studied. The investigation revealed that cooling capacity increased with ceramic porosity, the average rate of increase was $4.89\left(\mathrm{~W} / \mathrm{m}^{2}\right) / \%$. Cooling capacity decreased with ceramic wall thickness, the average rate of decrease was $1.03\left(\mathrm{~W} / \mathrm{m}^{2}\right) / \mathrm{mm}$. The ceramic wall thickness should therefore be as small as possible within the constraints of structural strength requirements. Cooling capacities can be enhanced by inserting copper wool into the ceramic; the average rate of increase was $8.2 \%$. A temperature drop of $3.8^{\circ} \mathrm{C}$ per square metre of ceramic surface area was achieved for a room with an internal volume of $18 \mathrm{~m}^{3}$ fitted with a chilled ceiling using the indirect evaporative cooler.

\section{References}

Costelloe, B., and Finn, D., 2003, "Indirect Evaporative Cooling Potential in Air-Water System in Temperature Climates," Energy and Buildings, Vol. 35, pp. 573-591.

Gasparella, A., and Longo, G. A, 2003, "Indirect Evaporative Cooling and Economy Cycle in Summer Air Conditioning," International Journal of Energy Research, Vol. 27, No. 7, pp. 625-637.

Joudi, A. K., and Mehdi, M. S., 2000, "Application of Indirect Evaporative Cooling to Variable Domestic Cooling Load," Energy Conversion \& Management, Vol. 41, pp. 1931-1951.

Riffat, B. S., 2001, "Cooling Apparatus (Porous pot),“ Patent No. PCT/GB00/04025.

Suri, R. K., 2001, "Energy-Saving Potential of an Indirect Evaporative Cooler," Applied Energy, Vol. 69, No. 1, pp. 69-76.

\section{Acknowledgements}

This project was funded by the Engineering and Physical Sciences Research Council, UK. 